\title{
Occurrence of sensory defects in semi-hard ewe's raw milk cheeses
}

\author{
L. Zabaleta ${ }^{1} \cdot$ M. Albisu ${ }^{1} \cdot$ M. Ojeda ${ }^{1}$ - P. F. Gil ${ }^{1}$ • \\ I. Etaio $^{1}$ - F. J. Perez-Elortondo ${ }^{1}$. \\ M. de Renobales ${ }^{1}$ - L. J. R. Barron ${ }^{1}$
}

Received: 3 December 2014 / Revised: 14 May 2015 / Accepted: 18 May 2015 /

Published online: 4 June 2015

(C) INRA and Springer-Verlag France 2015

\begin{abstract}
Sensory quality is one of the most important attributes of cheeses, as consumers demand homogeneous and unaltered products. The presence of sensory defects in the final product causes financial losses and consequently has a great economic impact on cheese makers. Therefore, a study was conducted to find out main defects that affect sensory quality: eyes, paste, rind, flavour, texture and shape of commercial semi-hard ewe's raw milk cheeses. The frequency of occurrence of relevant sensory defects in cheeses with different ripening times and those manufactured in different seasons was also investigated. Samples were collected along 5 years during the annual sensory quality control from different cheese makers. Although flavour is a major determinant of consumer acceptance, most common defects were those related to the internal appearance, especially cracks, which were more frequent in summer cheeses, and caverns, which were more frequent in spring and winter cheeses. White paste, soft texture and acid flavour defects were more frequent in cheeses with shortripening period. Medium- and long-ripened cheeses presented a higher percentage of an excess of rind halo with a darker paste colour, animal flavour and marks in the rind. Due to compositional milk changes throughout cheesemaking seasons, cheese makers should adapt their manufacturing practises to those changes and try to achieve uniform cheeses. The results found in this study may be useful for the quality improvement of semi-hard ewe's raw milk cheeses.
\end{abstract}

Keywords Sensory quality · Defect $\cdot$ Ewe's raw milk cheese $\cdot$ Seasonality Ripening

L. Zabaleta

laura.zabaleta@ehu.es

1 Lactiker Research Group. Pharmacy and Food Science Department, Faculty of Pharmacy,

University of the Basque Country, UPV/EHU, Paseo de la Universidad 7, 01006 Vitoria-Gasteiz, Spain 


\section{Introduction}

Around $60 \%$ of global sheep milk cheese is manufactured in Europe, mainly in Mediterranean countries such as Greece, Italy and Spain (FAO 2014). Spanish sheep milk cheese production increased by $28 \%$ between 2002 and 2012 (FAO 2014). Ewes are mainly milked for the manufacture of typical dairy products, in particular cheeses, which often have a regional or local connotation of origin and quality (Boyazoglu and Morand-Fehr 2001). Local cheese production is an important economic activity, especially in Mediterranean countries (Caridi et al. 2003). In some cases, these cheese varieties have a strong brand image that connects the product to characteristic sensory attributes, to a particular animal management conditions and to traditional cheesemaking methods. That plays a positive role in the choice of the product by consumers (Boyazoglu and Morand-Fehr 2001). Sensory quality is one of the most important attributes of a food product, determined by its flavour, texture and appearance. The relative importance of these three quality attributes is interrelated but unfortunately these relationships have not been studied in depth. Initial microbiological and physicochemical characteristics of raw milk, as well as technological treatments, affect the different phases of the production and hence the final quality of the product (Mahaut et al. 2003). Any change in any of these milk characteristics and/or an incorrect processing, particularly in raw milk cheeses, may result in a lack of some desirable organoleptic attributes or in the presence of an undesirable defect (Pirisi et al. 2007). The presence of defects in the final product causes financial losses and consequently has a great economic impact on the dairy industry (Engel et al. 2001).

The most studied defect is late blowing, as it is one of the major causes of spoilage in semi-hard and hard cheeses. It is predominantly caused by the growth of Clostridium tyrobutyricum that produces both texture and flavour defects (Feligini et al. 2014; Garde et al. 2012; Le Bourhis et al. 2007). Amongst cheese flavour characteristics, bitterness and unclean flavour (animal) have been particularly studied because of the consequences of economic loss, as these defects limit consumer acceptance (Engel et al. 2001). Studies reported in the literature concerning defects were mainly conducted with non-commercial or experimental cow's milk cheeses with induced defects at laboratory scale. Defects were studied separately and independently rather than investigating interactive effects that could arise amongst them.

Ripening is a major factor in determining the quality of small ruminant dairy products (Boyazoglu and Morand-Fehr 2001). It influences development of sensory characteristics of cheeses due to its effect on the chemical composition such as moisture loss, enzymatic activities including degradation of residual lactose, the lipolysis of fat increasing the total amount of free fatty acids and the proteolysis of casein leading to the production of amino acids and flavour precursors (Virto et al. 2003).

In the same way, seasonality is a major source of variation especially for farmhouse cheese makers that practise pasture feeding and seasonal milk production (Barron et al. 2001; Farruggia et al. 2014). In those cases, the effects of both changes in feed sources and farm practises are interactive and cannot be separated (Kindstedt 2005). As a result of those sources of variability, a change in the frequencies of occurrence of sensory defects or differences in cheese's defect profile could be expected.

The aim of this study was to describe the main sensory defects that appear in semihard sheep raw milk cheeses, as well as interactions or relationships that may arise 
amongst them. The frequency of occurrence of relevant sensory defects in cheeses with different ripening times and those manufactured in different seasons was also investigated.

\section{Materials and methods}

\subsection{Sample collection}

Samples were collected during the annual sensory quality control of a semi-hard sheep's raw milk cheese variety over five consecutive years (2006-2010). Commercial cheeses were manufactured in 126 different dairies in a similar manner. Milk was acidified by starter cultures and coagulated by the addition of rennet (commercial or traditional lamb rennet paste) at $25-35^{\circ} \mathrm{C}$. The resulting curd was cut into rice-sized grains and heated to $35-37{ }^{\circ} \mathrm{C}$. Then, the curd was introduced into cylindrical 1-2 $\mathrm{kg}$ moulds, pressed and salted with saturated sodium chloride brine at $10-12{ }^{\circ} \mathrm{C}$ for $16-24 \mathrm{~h}$. Cheeses were ripened at $8-10{ }^{\circ} \mathrm{C}$ for at least 2 months. Cheese samples with at least one sensory defect were collected (1437 cheese samples).

In order to determine the possible influence of the ripening time on the presence of defects, cheeses were classified into three groups: short-ripened cheeses (from 60 to 90 days) with 1079 samples, medium-ripened cheeses (from 91 to 119 days) with 260 samples and long-ripened cheeses (from 119 days onwards) with 98 samples. Cheeses had to pass the sensory quality control before being sold. Since minimum cheese ripening was 2 months, the number of shortripened cheese samples submitted for the quality control was larger than mediumand long-ripened cheeses.

Cheeses were manufactured from December to August. Milk composition changes in this period because lactation spans from winter (early lactation) to summer (late lactation), and animal management and feeding are different in winter (animals are fed indoors with forages and concentrate), spring (part-time grazing) and summer (grazing and extensive management). In order to determine if there were differences in the presence of defects amongst cheeses made in different seasons, samples were classified into three different groups according to manufacturing date: winter cheeses (December 1st to March 31st) with 800 samples, 539 samples belonged to spring cheeses (April 1st to June 20th) and 98 samples manufactured in summer (June 21st to August 31st). Sample size of each group was different because cheese production decreased from the beginning (winter) to the end (summer) of lactation period.

\subsection{Sensory analysis}

Cheese samples were analysed in the Sensory Laboratory of the University of the Basque Country (LASEHU) by a trained sensory panel. Sensory quality control method was previously described (Pérez-Elortondo et al. 2007), and it was included in the accreditation scope of the LASEHU according to ISO 17025 (2005). A maximum of eight samples were analysed in each session by seven trained expert assessors. Six 
parameters were analysed: shape, rind, paste, eyes, texture and flavour, on a sevenpoint category scale ( 1 being the minimum and 7 the maximum score). The method included a catalogue describing 44 possible specific defects for this cheese variety. The presence of a specific defect in the cheese sample was recorded when at least five of the seven assessors marked it. Defects with a minimum mean frequency of occurrence of $2.5 \%$ were selected for this study. Descriptions of these defects and photographs of some of them are shown in Table 1 and Fig. 1, respectively. A database was created with the results of the sensory analyses.

\subsection{Statistical analysis}

The percentage of occurrence of each sensory quality parameter and defect in relation to the total number of defective cheese samples (samples with at least one defect) was calculated. Relative frequency of occurrence of defects in the cheese groups classified according to ripening time and season were compared using the Pearson's chi-square test $(P \leq 0.05)$. Multiple correspondence analysis (MCA) was applied to explore relationships between cheese defects. Those variables that showed weight values higher than $|0.5|$ in the factorial solution were included in the MCA. XLSTAT software (version 2011.2, Addinsoft, France) was used for the statistical analysis of the data.

Table 1 Sensory description of the selected defects

\begin{tabular}{|c|c|c|}
\hline Parameter & Specific defect & Description \\
\hline \multirow[t]{5}{*}{ Eyes } & Caverns & Irregular large holes in paste \\
\hline & Cracks & Lineal openings in paste \\
\hline & Numerous & Too many holes in paste \\
\hline & Round & Round holes in paste \\
\hline & Badly distributed & Irregular distribution of holes in paste \\
\hline \multirow[t]{4}{*}{ Paste colour } & Excess of rind halo & Too dark or wide paste border \\
\hline & Irregular & Irregular colorations in paste \\
\hline & Dark & Too dark paste colour \\
\hline & White & Too white paste colour \\
\hline \multirow[t]{3}{*}{ Rind } & Black spots & Black spots in rind \\
\hline & Colourings & Irregular colorations in rind \\
\hline & Marks & Marks from the trays in the cheese rind \\
\hline \multirow[t]{3}{*}{ Flavour } & Acid & Flavour sensation of white wine vinegar or lactic acid \\
\hline & Animal & Flavour sensation reminiscent of cowshed or faecal \\
\hline & Bitter & Elementary taste produced by substances such as quinine \\
\hline \multirow[t]{2}{*}{ Texture } & Melty & Forms a paste with saliva and continuously melts \\
\hline & Soft & Little resistance to deformation in mouth \\
\hline \multirow[t]{3}{*}{ Shape } & Swollen & Markedly convex faces \\
\hline & Convex & Markedly convex sides \\
\hline & Inclined & Sides with different heights \\
\hline
\end{tabular}




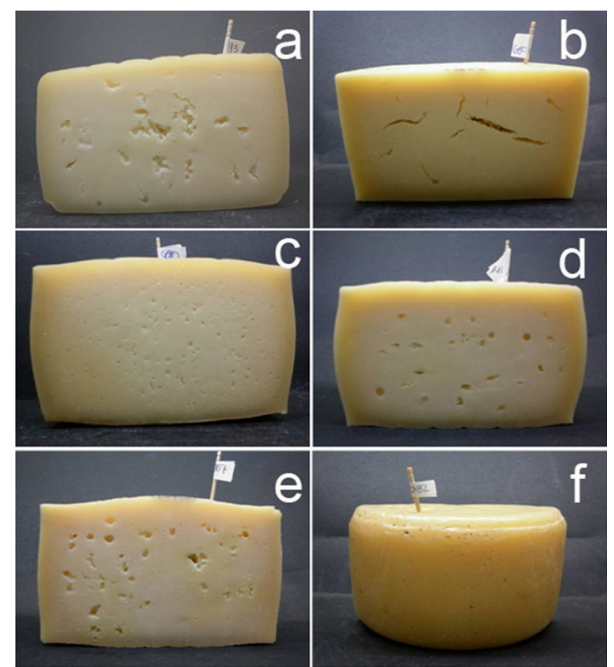

Fig. 1 Cross section of six defective cheeses. Caverns, marks, inclined and white paste (a); cracks, dark paste and excess of rind halo (b); numerous holes, irregular paste colour and white paste (c); round holes and excess of rind halo (d); swollen shape, round holes, caverns and paste irregular colour (e); and black spots (f)

\section{Results and discussion}

\subsection{Frequency of occurrence of relevant sensory defects}

Table 1 shows the specific defects found in each of the sensory quality parameters (eyes, paste colour, rind, flavour, texture and shape) during the studied period. This table includes those defects which were found at least with mean frequency of occurrence of $2.5 \%$ in the cheese samples. The data from the 5 years studied showed slight variations in the percentages of the different defects, with no major changes in the trend of their appearance. Therefore, the average results of this period were considered.

The most frequently observed defects were those related to the eyes (Table 2). Caverns and cracks in the paste were frequent defects in the cheese samples. Defective openings have been described in the literature in different types of cheese. It is difficult to find a specific cause for this problem because many agents could cause it, such as microbial growth, abnormal mineral composition, inadequate draining and ripening conditions (Mahaut et al. 2003). Eyes are mainly caused by hydrogen gas and carbon dioxide produced by the metabolism of Clostridium spp. (Le Bourhis et al. 2007) or other microorganisms such as coliforms, yeasts and heterofermentative lactic acid bacteria that can also be involved in gas production during cheese ripening (Mahaut et al. 2003). The formation of different kinds of holes in ripened cheeses is influenced by the type and amount of gas produced, cheese texture and effect of temperature on gas solubility within the cheese (Sheehan 2011). Openings could also be mechanically originated by an insufficient or fast pressing (Ortiz 2005). Other authors suggested that an excessively intense curd draining could give a friable consistency to the cheese paste originating cracks in paste and rind (Tornadijo et al. 1998). 
Table 2 Percentage of defective cheese samples showing at least one specific defect during the period 20062010

\begin{tabular}{|c|c|c|c|c|c|c|c|}
\hline \multirow[t]{3}{*}{ Defect } & \multicolumn{5}{|l|}{ Year } & \multicolumn{2}{|l|}{ Total } \\
\hline & 2006 & 2007 & 2008 & 2009 & \multirow[t]{2}{*}{2010} & & \\
\hline & \multicolumn{4}{|c|}{ Percentage of cheeses } & & Mean & Parameter $^{\mathrm{a}}$ \\
\hline Caverns & 40 & 55 & 35 & 45 & 39 & 43 & 74 Eyes \\
\hline Cracks & 26 & 21 & 29 & 25 & 29 & 26 & \\
\hline Numerous & 13 & 9 & 8 & 10 & 6 & 10 & \\
\hline Round & 14 & 8 & 7 & 9 & 9 & 9 & \\
\hline Badly distributed & 11 & 8 & 6 & 6 & 9 & 8 & \\
\hline Excess of rind halo & 32 & 29 & 24 & 23 & 23 & 27 & 35 Paste colour \\
\hline Irregular & 7 & 7 & 4 & 4 & 5 & 6 & \\
\hline Dark & 8 & 5 & 6 & 4 & 2 & 5 & \\
\hline White & 3 & 4 & 4 & 2 & 5 & 3 & \\
\hline Black spots & 19 & 14 & 12 & 15 & 10 & 14 & 30 Rind \\
\hline Colourings & 10 & 13 & 9 & 11 & 14 & 11 & \\
\hline Marks & 9 & 8 & 11 & 11 & 9 & 10 & \\
\hline Acid & 15 & 13 & 11 & 13 & 12 & 13 & 20 Flavour \\
\hline Animal & 8 & 3 & 7 & 4 & 3 & 5 & \\
\hline Bitter & 8 & 3 & 3 & 3 & 1 & 4 & \\
\hline Melty & 25 & 16 & 10 & 8 & 7 & 14 & 16 Texture \\
\hline Soft & 9 & 4 & 3 & 4 & 2 & 5 & \\
\hline Swollen & 8 & 4 & 6 & 11 & 11 & 8 & 15 Shape \\
\hline Convex & 8 & 5 & 3 & 4 & 2 & 4 & \\
\hline Inclined & 2 & 3 & 4 & 3 & 3 & 3 & \\
\hline
\end{tabular}

${ }^{\text {a }}$ Percentage of samples with at least one defect related with the parameter. The same sample could have more than one defect

Main paste colour defects were the presence of an excessive rind halo, an irregular colour and a too dark or too white paste colour (Table 2). As ripening progresses, cheeses lose moisture and the colour of the paste becomes darker. An excess amount of salt or an inadequate ripening, with high temperatures or excessive air velocity, can contribute to an excessive loss of moisture and thus be the cause of the dark paste colour of cheeses. The irregular paste colour is mainly due to a non-homogeneous particle size of the grain during curd cutting, resulting in a paste with nonhomogeneous moisture giving defective fermentations (Mahaut et al. 2003; McSweeney 2007).

Black spots, unwanted yellow and orange colourations and tray marks were the predominant rind defects (Table 2). Black spots were described in the paste of Cheddar cheese as a consequence of residual levels of a commercial intramammary teat sealant containing bismuth subnitrate. In this case, the black spots were solid amorphous structures of bismuth salts in the cheese (Lay et al. 2007). The problem of abnormal colouring in the rind may be due to colonisation by yeasts, moulds or bacterial 
populations influenced by environmental factors, especially in the airing area and ripening chambers (Amato et al. 2012; Mahaut et al. 2003; McSweeney 2007). This contamination does not usually produce a severe flavour problem (Ortiz 2005). Tray marks are usually caused by an insufficient turning of the cheeses during ripening.

Excessive acidity, animal (dirty) aromas and bitter flavour were the most frequent flavour defects (Table 2). Numerous studies pointed out that the type and amount of starter culture, $\mathrm{pH}$ of the milk and curd, brining, ripening conditions, and variations in cheese composition can exert an important influence on cheese flavour (Margrete et al. 2009). However, the origin of a specific flavour defect could be unknown due to the complexity of the cheese matrix and the possible interactions between its components during cheese ripening (Engel et al. 2001; Smit et al. 2005). An excessive acidity could be originated by a large amount of starter culture added to the vat milk, an irregular curd cutting, an insufficient amount of salt, high moisture content of cheese or high temperature in the ripening chamber (Ortiz 2005). In relation with other flavour defects, it has been found that the bacterial metabolism had a significant impact in the development of off-flavours such as bitter, meaty, brothy, putrid, faecal and unclean flavour in Cheddar cheese. These off-flavours can originate from the catabolism of aromatic amino acids during cheese ripening. Catabolism of L-tryptophan, tyrosine and phenylalanine leads to the formation of indole, skatole, tryptamine, $m$-cresol, $p$-cresol, phenol, benzoic acid and phenethanol which are responsible for unclean flavours in some cheese varieties (Ummadi and Weimer 2001). Bitterness has been considered as the major cheese flavour defect for some matured cheese varieties, and in some cases, as for Cheddar cheese, it can become a serious economic concern (Engel et al. 2001). Some authors reported that amino acids and peptides originated by hydrolysis of caseins are responsible for bitter flavour in ripened cheeses (Broadbent et al. 2002; Engel et al. 2001; McSweeney 2007). However, in this study only 4\% of the cheese samples showed bitter flavour (Table 2).

Main texture problems were melty (adhesiveness) and excessively soft cheeses. It has been described that it may be due to insufficient curd draining caused by slow acidification originated by too low room temperature when pressing the paste. Consequently, the cheese paste shows high water activity value, which favours enzyme and microbial activities, and therefore an excessive proteolysis (McSweeney 2007). Other authors linked these texture defects with the type and amount of rennet used for cheesemaking (Pirisi et al. 2007).

Shape defects such as swollen and convex cheeses (Table 2) were primarily due to technologically related problems. The swollen defect occurs frequently in many cheese varieties and is usually due to the formation of gas by different types of microorganisms. It could be caused by the starter culture formulation with an excess of lactic acid heterofermentative bacteria, by a lack of hygiene in milking and cheesemaking or by contamination of Clostridium spp. that often are associated with animal silage feeding (Garde et al. 2012; McSweeney. 2007). A very low-level contamination (0.01 cfu/mL) of butyric acid bacteria can cause late blowing defect in Gouda-type cheeses (Vissers et al. 2006). As a result of the bacterial metabolism, this contamination often comes with an increase in acidic compounds, mainly butyric acid, and gas production. The resulting cheeses present large caverns and off-flavours. Late blowing is considered one of the major causes of spoilage in semi-hard and hard cheeses (Garde et al. 2012; Le Bourhis et al. 2007). 


\subsection{Cheeses of different ripening times}

Table 3 shows the defects which were significantly $(P \leq 0.05)$ different between cheese samples of different ripening times (short-, medium- and long-ripened cheeses). The frequency of cheeses with a white paste and a soft texture was significantly higher in short-ripened cheeses than in medium- and long-ripened cheeses. It was also found that excessive acidity and melty texture affected short-ripened cheeses more than those with a longer ripening period (Table 3). Those defects, which were more frequent in shortand medium-ripened cheeses, could be caused by an insufficient draining of the cheese. Excessive whey retention may be due to a low temperature in the press, an insufficient activity of lactic acid bacteria or a weak pressing of the cheese curd (Kindstedt 2005). Furthermore, cheeses with high moisture have high concentrations of whey and lactose, and therefore the lactic acid bacteria can produce a large amount of lactic acid, and consequently, the acidity of the cheese will be high (Kindstedt 2005). Medium- and

Table 3 Percentage of cheese samples with specific defects according to different ripening times and seasons

\begin{tabular}{|c|c|c|c|c|c|c|c|}
\hline \multirow[t]{2}{*}{ Parameter } & \multirow[t]{2}{*}{ Defect } & \multicolumn{3}{|c|}{ Ripening time ${ }^{1}$} & \multicolumn{3}{|c|}{ Season $^{2}$} \\
\hline & & Short & Medium & Long & Winter & Spring & Summer \\
\hline \multirow[t]{5}{*}{ Eyes } & Caverns & 44 & 41 & 37 & $45^{\mathrm{a}}$ & $41^{\mathrm{a}}$ & $30^{\mathrm{b}}$ \\
\hline & Cracks & 26 & 25 & 28 & $23^{\mathrm{b}}$ & $27^{\mathrm{a}, \mathrm{b}}$ & $35^{\mathrm{a}}$ \\
\hline & Numerous & 9 & 13 & 7 & $8^{\mathrm{b}}$ & $12^{\mathrm{a}}$ & $9^{\mathrm{a}, \mathrm{b}}$ \\
\hline & Round & 9 & 8 & 12 & $8^{\mathrm{b}}$ & $12^{\mathrm{a}}$ & $11^{\mathrm{a}, \mathrm{b}}$ \\
\hline & Badly distributed & 8 & 7 & 13 & $8^{\mathrm{a}, \mathrm{b}}$ & $10^{\mathrm{a}}$ & $3^{\mathrm{b}}$ \\
\hline \multirow[t]{4}{*}{ Paste colour } & Excess of rind halo & $23^{\mathrm{c}}$ & $33^{\mathrm{b}}$ & $53^{\mathrm{a}}$ & $27^{\mathrm{a}}$ & $30^{\mathrm{a}}$ & $10^{\mathrm{b}}$ \\
\hline & Irregular & 5 & 6 & 9 & $5^{\mathrm{b}}$ & $5^{\mathrm{b}}$ & $14^{\mathrm{a}}$ \\
\hline & Dark & $4^{\mathrm{b}}$ & $8^{\mathrm{a}}$ & $15^{\mathrm{a}}$ & 5 & 6 & 2 \\
\hline & White & $4^{\mathrm{a}}$ & $1^{\mathrm{b}}$ & $0^{\mathrm{b}}$ & 4 & 3 & 4 \\
\hline \multirow[t]{3}{*}{ Rind } & Black spots & 14 & 13 & 17 & 15 & 13 & 13 \\
\hline & Colourings & 10 & 15 & 13 & $10^{\mathrm{b}}$ & $12^{\mathrm{b}}$ & $19^{\mathrm{a}}$ \\
\hline & Marks & $8^{\mathrm{b}}$ & $13^{\mathrm{a}}$ & $15^{\mathrm{a}}$ & 9 & 10 & 11 \\
\hline \multirow[t]{3}{*}{ Flavour } & Acid & $14^{\mathrm{a}}$ & $10^{\mathrm{a}, \mathrm{b}}$ & $4^{\mathrm{b}}$ & $16^{\mathrm{a}}$ & $9^{\mathrm{b}}$ & $10^{\mathrm{a}, \mathrm{b}}$ \\
\hline & Animal & $4^{\mathrm{b}}$ & $10^{\mathrm{a}}$ & $11^{\mathrm{a}}$ & $4^{\mathrm{b}}$ & $8^{\mathrm{a}}$ & $3^{\mathrm{b}}$ \\
\hline & Bitter & 4 & 4 & 1 & 4 & 4 & 2 \\
\hline \multirow[t]{2}{*}{ Texture } & Melty & $15^{\mathrm{a}}$ & $12^{\mathrm{a}}$ & $5^{\mathrm{b}}$ & $16^{\mathrm{a}}$ & $11^{\mathrm{b}}$ & $14^{\mathrm{a}, \mathrm{b}}$ \\
\hline & Soft & $6^{\mathrm{a}}$ & $1^{\mathrm{b}}$ & $0^{\mathrm{b}}$ & $7^{\mathrm{a}}$ & $2^{\mathrm{b}}$ & $1^{\mathrm{b}}$ \\
\hline \multirow[t]{3}{*}{ Shape } & Swollen & 9 & 7 & 2 & $10^{\mathrm{a}}$ & $5^{\mathrm{b}}$ & $5^{\mathrm{b}}$ \\
\hline & Convex & 5 & 4 & 5 & 5 & 6 & 7 \\
\hline & Inclined & 3 & 2 & 5 & 3 & 3 & 3 \\
\hline
\end{tabular}

${ }^{\mathrm{a}, \mathrm{b}, \mathrm{c}}$ Different letters in the same row within the same comparing group indicate significant differences $(P \leq$ $0.05)$

${ }^{1}$ Short-ripened from 60 to 90 days, medium-ripened from 91 to 119 days and long-ripened from 119 days onwards

${ }^{2}$ Winter from December 1st to March 31st, spring from April 1st to June 20th and summer from June 21st to August 31st 
long-ripened cheeses presented a higher percentage of an excess of rind halo with a darker paste colour, stronger animal flavour and more marks in the rind than shortripened cheeses (Table 3). The compositional changes caused by the loss of moisture and biochemical processes during cheese ripening could affect texture, colour and flavour making them harder, with a darker colour and stronger flavour than the less ripened cheeses. It has been reported that high humidity and temperature in the ripening chambers can cause colour defects (Ortiz 2005).

\subsection{Cheeses manufactured in different seasons}

Table 3 shows defects with significantly $(P \leq 0.05)$ different frequencies of occurrence between cheeses made in winter, spring and summer. Cheeses with swollen shape, caverns and badly distributed eyes were more frequent in winter and spring cheeses than in summer cheeses. Cheese blowing and the presence of abnormally shaped or excessively big eyes have been related to late blowing defect, caused by contamination with spores of Clostridium spp. that metabolise lactate producing acetic and butyric acids, and gas (carbon dioxide and hydrogen) (Le Bourhis et al. 2007; Sheehan 2011). Silage feeding, common practise during winter, has been reported as a possible source of this kind of contamination. In contrast, some authors have found higher Clostridium spp. spore counts in summer milk than in milk from other seasons (Garde et al. 2011). In addition, frequency of occurrence of cheeses with acid flavour and soft and melty texture was higher in cheeses made in winter than in cheeses manufactured in spring (Table 3). Those defects could be caused by a high moisture content of the cheese paste. As discussed above, low temperatures in the press could affect the draining of the cheese. The low calcium content in winter milk could also (Nájera et al. 2009) hinder curd draining, resulting in a moister paste. For this reason, winter cheeses could be softer and with more lactose available to be transformed into lactic acid than spring and summer cheeses (McSweeney 2007).

Spring cheeses showed higher proportion of numerous and round holes in the paste and stronger animal flavour than winter cheeses. In spring, grazing begins, with high air humidity and a higher likelihood of contamination of the udders. These conditions and the higher temperatures stimulate the growth of microorganisms such as coliforms in milk which can cause these defects (Walstra et al. 2001).

Cracks, irregular paste and rind colourings were frequent in summer cheeses (Table 3). Milk production decreases in summer, so more milkings are often combined to have sufficient milk volume for cheesemaking (Endrizzi et al. 2012). Consequently, milk is cold stored for long periods (up to $48 \mathrm{~h}$ ) favouring the proliferation of psychrotrophs in milk. Proteolytic activity of psychrotrophs could negatively affect curd formation and consistency (Fonseca et al. 2012; Malacarne et al. 2013), resulting in a paste that cracks easily after pressing. Furthermore, high summer temperatures could increase dairy environmental proliferation of microorganisms, such as Clostridium spp., responsible for gas production which could also originate cracks in the paste. Garde et al. (2011) reported that the highest incidence of late blowing defect for Manchego cheeses produced in summer correlated with high clostridial spore counts in summer milk. In addition, milk fat content was higher in summer (at the end of lactation period) than in spring and winter. Summer cheese fat was also more unsaturated due to the extensive grazing management of flocks during this season. As it 
is well-known, fresh grass is a source of polyunsaturated fatty acids, and when it is ingested by ruminants, the content of these fatty acids in milk and therefore in cheese increases. Although scientific data are very scarce, particularly for sheep milk, changes in fat content can affect fat globule structure and size (Walstra et al. 2006; Lopez et al. 2007), and the mechanical strength of cheese paste could be reduced resulting in the appearance of cracks during cheese ripening (McSweeney 2007). The increase of fat content could also impede a homogeneous whey draining (Kindstedt 2005), and in consequence, an improper draining could result in an irregular colouring of the cheese paste. The appearance of colourations in the rind may be due to an environmental contamination during ripening by moulds and yeasts, particularly when the temperature is excessively high in the ripening chamber (Mahaut et al. 2003).

\subsection{Relationships between defects}

Figure 2 shows the factorial map corresponding to the first two factors resulting from the MCA that explained the $66.13 \%$ of the total inertia. Factor F1, which explained $45.38 \%$ of total inertia grouped (weight values higher than $|0.5|$ ) white, soft, bitter, melty, acid, marks, dark, swollen and excess of rind halo defects. In this factor, defects with positive values were those frequently found in short-ripened cheeses, whereas those with negative values were more frequent in long-ripened cheeses. When cheeses present high moisture content, they also retain less salt, favouring microorganism growth, and consequently, a higher proteolysis is produced during cheese ripening. Therefore, the cheese will present a weaker texture and a bitter and acid taste. Other authors also found a soft and sticky texture in cheeses with high moisture (Tornadijo et al. 1998). Bitter flavour and texture defects have also been described when proteolytic enzymes were added to vat milk to accelerate cheese ripening (Izco et al. 2000).

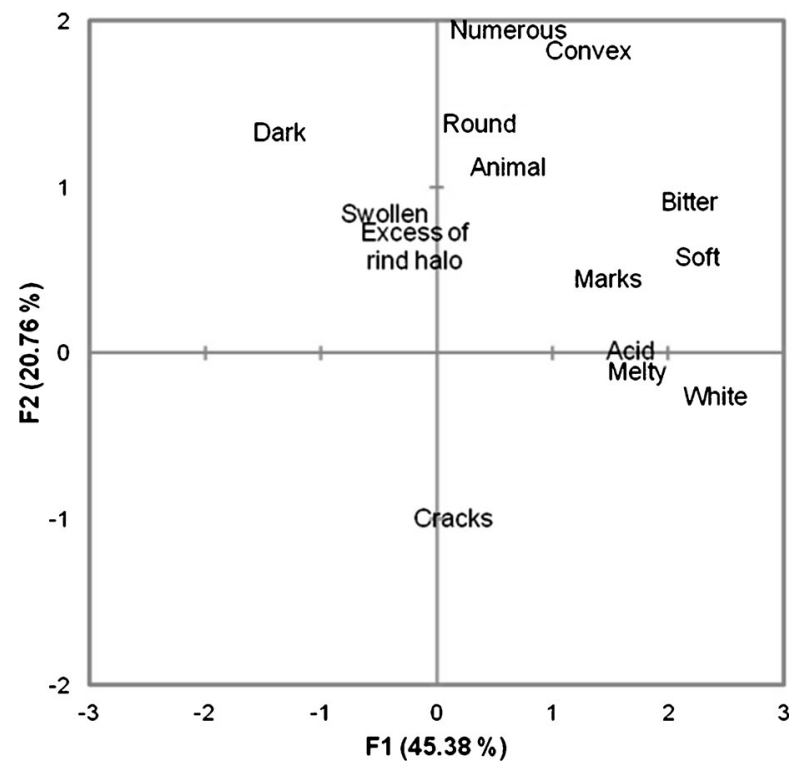

Fig. 2 Multiple correspondence analysis of the defects in cheese samples. Only defects with a minimum weight of $|0.5|$ in at least one factor are shown 
Cheeses with soft texture may exhibit frequent rind marks because they may have not been turned as often as needed.

Defects with negative weight values in factor F1 were swollen, excess of rind halo and dark paste colour. Those defects had been discussed when the cheese samples of different ripening times were compared. As mentioned before, the swollen defect could be the result of the proliferation of Clostridium spp.

Factor F2, which accounts for $20.76 \%$ of total inertia grouped convex cheeses, numerous and round eyes, and animal flavour all with positive weight values, and cracks with negative weight values. As discussed above, coliforms can be the major cause for the presence of numerous small round eyes, which are often related with dirty and putrid flavour (Ortiz 2005). The origin of cracks, observed more often in summer, may be caused by gas production from the growth of microorganisms as a result of the storage of milk for several days or the metabolism of clostridial bacteria.

\section{Conclusion}

Flavour is one of the main sensory parameters to assess cheese quality. In this study, it was one of the least affected sensory quality parameters along with texture and shape. The most frequent flavour and texture problems were excessive acidity and melty texture, primary found in short- and medium-ripened cheeses. For this reason, cheeses could be best commercialised after 4 months of ripening. In contrast, the eyes were the most frequently affected sensory quality parameter. Cracks and caverns in the cheese paste were not associated with flavour defects as evidenced by the MCA. The caverns were more frequent in spring and winter cheeses whereas the cracks were more frequent in summer cheeses. Because flock management and cheesemaking conditions differ in winter and in summer, the appearance of different types of openings at these times suggests different origins. However, in the literature, authors often describe different types of openings in an undifferentiated manner as eyes, thus making the interpretation of their results difficult. On the other hand, the ripening period did not affect the frequency of the defects related with eyes and shape, suggesting that these problems may appear within the first 2 months of ripening. Early quality control could avoid the costs associated with the ripening cheeses with defective openings. Due to compositional milk changes and environmental changes throughout cheesemaking seasons, cheese makers should modify their manufacturing practises according to seasons. For example, cheeses made in winter should be turned more often than those made in summer. In order to prevent fermentation by unwanted microorganisms, special care should be taken when environmental temperature is high. After a hygienic milking, milk should be rapidly cooled and stored at low temperature for the shortest time possible prior to cheese manufacture. Hygienic practises should be maintained throughout the whole cheesemaking process, and an active starter culture that rapidly metabolises lactose and acidifies milk should be used. Cutting of curd should be standardised in order to obtain a homogeneous grain size and thus an uniform draining. The results found in this study may be useful for the quality improvement of semi-hard ewe's raw milk cheeses. 
Acknowledgments This study was supported by the Training and Research Unit on Food Quality and Safety of the University of the Basque Country, Departments of Industry (SA-2010/00113), Education, Language Policy and Culture (IT766-13), and Agriculture of the Basque Government. The authors thank the sensory assessors and Luis Guerrero for statistical assistance.

Conflict of interest L. Zabaleta, M. Albisu, M. Ojeda, P. F. Gil, I. Etaio, F.J. Perez-Elortondo, M. de Renobales and L.J.R. Barron declare that they have no conflict of interest.

Compliance with ethics requirements This article does not contain any studies with human or animal subjects performed by any of the authors.

\section{References}

Amato L, Ritschard JS, Kurtz O, Arias-Roth E, Lacroix C, Schuppler M, Meile L (2012) Microbial composition of defect smear - a problem evolving during foil-prepacked storage of red-smear cheeses. Int Dairy J 27:77-85

Barron LJR, Fernández de Labastida E, Perea S, Chávarri F, de Vega C, Soledad Vicente M, Isabel Torres M, Isabel Nájera A, Virto M, Santisteban A, Pérez-Elortondo FJ, Albisu M, Salmerón J, Mendía C, Torre P, Clemente Ibáñez F, de Renobales M (2001) Seasonal changes in the composition of bulk raw ewe's milk used for Idiazabal cheese manufacture. Int Dairy J 11:771-778

Boyazoglu J, Morand-Fehr P (2001) Mediterranean dairy sheep and goat products and their quality: a critical review. Small Rumin Res 40:1-11

Broadbent JR, Barnes M, Brennand C, Strickland M, Houck K, Johnson ME, Steele JL (2002) Contribution of Lactococcus lactis cell envelope proteinase specificity to peptide accumulation and bitterness in reducedfat Cheddar cheese. Appl Environ Microbiol 68:1778-1785

Caridi A, Micari P, Caparra P, Cufari A, Sarullo V (2003) Ripening and seasonal changes in microbial groups and in physico-chemical properties of the ewes' cheese Pecorino del Poro. Int Dairy J 13:191-200

Endrizzi I, Fabris A, Biasioli F, Aprea E, Franciosi E, Poznanski E, Cavazza A, Gasperi F (2012) The effect of milk collection and storage conditions on the final quality of Trentingrana cheese: sensory and instrumental evaluation. Int Dairy J 23:105-114

Engel E, Nicklaus S, Septier C, Salles C, Le Quéré JL (2001) Evolution of the taste of a bitter Camembert cheese during ripening: characterization of a matrix effect. J Agric Food Chem 49:2930-2939

FAO (2014) FAOSTAT Domains. Production. Livestock Primary. http:/faostat3.fao.org/faostat-gateway/go/ to/download/Q/QL/E. Accessed 12 May 2014

Farruggia A, Pomiès D, Coppa M, Ferlay A, Verdier-Metz I, Le Morvan A, Bethier A, Pompanon F, Troquier O, Martin B (2014) Animal performances, pasture biodiversity and dairy product quality: how it works in contrasted mountain grazing systems. Agric Ecosyst Environ 185:231-244

Feligini M, Brambati E, Panelli S, Ghitti M, Sacchi R, Capelli E, Bonacina C (2014) One-year investigation of Clostridium spp. occurrence in raw milk and curd of Grana Padano cheese by the automated ribosomal intergenic spacer analysis. Food Control 42:71-77

Fonseca CR, Bordin K, Neeff DV, Oliveira CAF (2012) Growth of psychrotrophic bacteria in raw goat milk and correlations with lipolytic and proteolytic activities. Bulletin of the IDF 16-18

Garde S, Arias R, Gaya P, Nuñez M (2011) Occurrence of Clostridium spp. in ovine milk and Manchego cheese with late blowing defect: identification and characterization of isolates. Int Dairy J 21:272-278

Garde S, Ávila M, Gaya P, Arias R, Nuñez M (2012) Sugars and organic acids in raw and pasteurized milk Manchego cheeses with different degrees of late blowing defect. Int Dairy J 25:87-91

I.S.O. 17025 (2005) General requirements for the competence of testing and calibration. International Organization for Standardization. Geneva, Switzerland

Izco JM, Irigoyen A, Torre P, Barcina Y (2000) Effect of the activity levels of the added proteolytic enzyme mixture on free amino acids in ripening Ossau-Iraty cheese. J Chromatogr A 881:69-79

Kindstedt P (2005) American farmstead cheese: the complete guide to making and selling artisan cheeses. Chelsea Green Publishing Company, White River Junction

Lay AM, Kolpin KM, Sommer DA, Rankin SA (2007) Hot topic: black spot defect in Cheddar cheese linked to intramammary teat sealant. J Dairy Sci 90:4938-4941 
Le Bourhis A, Doré J, Carlier J, Chamba J, Popoff M, Tholozan J (2007) Contribution of C. beijerinckii and C. sporogenes in association with C. tyrobutyricum to the butyric fermentation in Emmental type cheese. Int J Food Microbiol 113:154-163

Lopez C, Camier B, Gassi JY (2007) Development of the milk fat microstructure during the manufacture and ripening of Emmental cheese observed by confocal laser scanning microscopy. Int Dairy J 17:235-247

Mahaut M, Jeanet R, Brulé G (2003) Initiation à la technologie fromagère. [Introduction to cheese making technology]. Tec et Doc, Paris

Malacarne M, Summer A, Franceschi P, Formaggioni P, Pecorari M, Panari G (2013) Effects of storage conditions on physico-chemical characteristics, salt equilibria, processing properties and microbial development of raw milk. Int Dairy J 29:36-41

Margrete E, Øystein H, Harald V, Knut H (2009) Fat content, fatty acid profile and off-flavours in goats milk - effects of feed concentrates with different fat sources during the grazing season. Anim Feed Sci Technol 152:112-122

McSweeney PLH (2007) Cheese problems solved. Woodhead Publ, Cambridge

Nájera AI, Barron LJR, Ribeiro P, Pèlissier F, Abilleira E, Pérez-Elortondo FJ, Albisu M, Salmerón J, Ruiz de Gordoa JC, Virto M, Oregi L, Ruiz R, de Renobales M (2009) Seasonal changes in the technological and compositional quality of ewe's raw milks from commercial flocks under part-time grazing. J Dairy Res 76:301-307

Ortiz MA (2005) Problemática de los quesos de vaca, oveja, cabra y mezcla. [Problems of cheeses from cow, sheep, goat, and mixture milks]. Ayala AMV, Madrid

Pérez-Elortondo FJ, Ojeda M, Albisu M, Salmerón J, Etayo I, Molina M (2007) Food quality certification: an approach for the development of accredited sensory evaluation methods. Food Qual Prefer 18:425-439

Pirisi A, Pinna G, Addis M, Piredda G, Mauriello R, De Pascale S, Caira S, Mamone G, Ferranti P, Addeo F, Chianese L (2007) Relationship between the enzymatic composition of lamb rennet paste and proteolytic, lipolytic pattern and texture of PDO Fiore Sardo ovine cheese. Int Dairy J 17:143-156

Sheehan JJ (2011) In: Fuquay JW, Fox PF, McSweeney PLH (eds) Encyclopedia of dairy sciences, 2nd edn. San Diego, Academic Press

Smit G, Smit BA, Engels WJM (2005) Flavour formation by lactic acid bacteria and biochemical flavour profiling of cheese products. FEMS Microbiol Rev 29:591-610

Tornadijo ME, Marra MI, Carballo J (1998) Alteraciones y defectos de los quesos. Alimentación, equipos y tecnología. [Alterations and defects in cheeses. Feeding, equipments and technology]. 67-77

Ummadi M, Weimer BC (2001) Tryptophan catabolism in Brevibacterium linens as a potential cheese flavor adjunct. J Dairy Sci 84:1773-1782

Virto M, Chávarri F, Bustamante MA, Barron LJR, Aramburu M, Vicente MS, Pérez-Elortondo FJ, Albisu M, de Renobales M (2003) Lamb rennet paste in ovine cheese manufacture. Lipolysis and flavour. Int Dairy J 13:391-399

Vissers MMM, Driehuis F, Te Giffel MC, De Jong P, Lankveld JMG (2006) Improving farm management by modeling the contamination of farm tank milk with butyric acid bacteria. J Dairy Sci 89:850-858

Walstra P, Geurts TJ, Noomen A, Jellema A, vanBoekel MAJS (2001) Ciencia de la leche y tecnología de los productos lácteos. [Milk science and dairy technology]. Acribia, Zaragoza

Walstra P, Wouters JTM, Geurts TJ (2006) Dairy science and technology, 2nd edn. CRC Pres, Boca Raton 